\title{
Peran Kelompok Perawatan Diri (KPD) dalam Upaya Mencegah Peningkatan Kecacatan pada Penderita Kusta
}

\author{
Puji Dwi Noratikasari $^{1}$, Yunus Ariyanto ${ }^{1}$, Mury Ririanty ${ }^{1}$ \\ ${ }^{1}$ Fakultas Kesehatan Masyarakat Universitas Jember
}

\section{ABSTRACT}

Background: Leprosy sufferers who were not treated immediately deteriorate their disease and increase the risk of complications such as permanent defects in skin, hands, feet and eyes. Disability in leprosy patients can be prevented by early diagnosis and routine treatment of multi drug therapy (MDT). Regular MDT only kill leprosy germs but not permanent defects that should need more optimal efforts. The role of KPD was to help lepers in facing disabilities and also to empower them in improving socio-economic status. This study aims to describe the roles of KPD in leprosy patients in Jember District.

Method: This is a descriptive study which conducted in two health centers in Jenggawah and Anggrek Sumberbaru. This study involved 27 leprosy patients which selected purposively (patient with permanent defects). Data was collected using partially structured questionnaire includes open ended question and observations. Data analysed using univariate, bivariate and categorizing open ended questionnaire.

Results: The role of KPD in two health centers has been conducted mostly in helping leprosy patient to do defects' self care. The KPDs also provided counseling and training to patient and family to take routine medication. The results also showed that the limited facilities including budget for doing self care by leprosy patients was the barriers to comply take complete medication. In terms of empowering the lepers, KPDs have done minimally because of limited resources. This study recommended that to improve the socio-economic patient needs to cooperate with other sectors including private parties in order to obtain more funding.
Correspondence

pujid134@gmail.com

\section{Article History}

Received 23 August 2019

Revised 24 January 2020

Accepted 14 January 2020

Available Online 6 March 2020

Keywords

Self-Care Group

Leprosy

Disability

\section{DOI}

10.14710/jpki.15.1.22-30

\section{PENDAHULUAN}

Kusta adalah salah satu penyakit menular yang masih menjadi permasalahan sampai dengan saat ini. Data dari WHO menunjukkan selama 10 tahun terakhir terjadi penurunan yang cukup lambat dalam pendeteksian baru kasus kusta, pada tahun 2008 sebesar 249.007 kasus menjadi 210.671 kasus pada tahun 2017. Tiga negara yang masih menyumbang beban kusta tertinggi adalah India, Brasil dan Indonesia. ${ }^{1}$

Jawa Timur adalah salah satu provinsi dengan beban kusta tertinggi yang berkontribusi besar terhadap jumlah kasus kusta di Indonesia. Secara nasional Jawa Timur menempati urutan pertama dengan jumlah kusta baru pada tahun 2017 sebesar 3.373 jiwa dengan proporsi pada lakilaki sebesar 2.033 jiwa $(60,3 \%)$ dan perempuan sebesar 1.340 jiwa (39,7\%). Wilayah di Provinsi Jawa Timur yang menyumbangkan kasus kusta terbanyak adalah Pulau Madura dan daerah tapal kuda. ${ }^{2}$

Kabupaten Jember memiliki tingkat perekonomian yang tinggi karena pusat perekonomian di Eks. Karesidenan
Besuki berada di Kabupaten Jember. Selain itu Kabupaten Jember merupakan salah satu sentral pendidikan dan kesehatan, dilihat dari lengkapnya berbagai fasilitas, termasuk fasilitas kesehatan jika dibandingkan dengan kabupaten disekitarnya. Kabupaten Jember sampai saat ini masih menjadi salah satu kabupaten dengan jumlah kusta tertinggi. $^{3}$

Jumlah kasus kusta yang ditemukan dari tahun 2015 sampai 2017 mengalami penurunan yang cukup signifikan, secara berturut-turut sebesar 378 jiwa, 353 jiwa, 147 jiwa. Pada tahun 2018 mengalami kenaikan kembali, sebesar $46,7 \%$ dari tahun sebelumnya. Jumlah kasus kusta pada tahun 2018 sebesar 214 jiwa dengan proporsi tipe PB (Paucibacillary) sebanyak 14 jiwa dengan persentase 6,6\% sedangkan tipe MB (Multibacillary) sebanyak 200 jiwa dengan persentase $93,4 \%$. Penderita kusta yang mengalami kondisi tanpa cacat sebanyak 126 jiwa dengan persentase sebesar 59\%, cacat I sebanyak 47 jiwa dengan persentase sebesar 22\%, dan cacat II sebanyak 41 jiwa dengan persentase sebesar $19 \%$ dan endemik di beberapa wilayah. ${ }^{4}$ 
Penyakit kusta dapat menyebabkan beberapa masalah yang diakibatkan karena persepsi yang salah, seperti anggapan bahwa penyakit tersebut merupakan penyakit kutukan, karena timbulnya luka yang menjijikkan hingga berakibat pada kecacatan. ${ }^{5}$ Penderita kusta yang tidak segera ditangani dan diobati akan mengakibatkan penyakit semakin memburuk dan meningkatkan risiko komplikasi, selain itu akan berakibat timbulnya kecacatan yang permanen baik pada kulit, tangan, kaki maupun mata. ${ }^{6}$

Kecacatan pada kusta mencakup tiga aspek di antaranya: kerusakan struktur dan fungsi (impairment, activity limitation, perticipation problem). ${ }^{7}$ Kecacatan yang dialami oleh penderita kusta sebenarnya dapat dicegah melalui diagnosis dini dan pengobatan secara teratur dan akurat melalui Multi Drug Therapy (MDT), walaupun kecacatan bisa juga terjadi selama proses dan setelah pengobatan. ${ }^{8}$ Pengobatan MDT secara teratur dan tuntas mampu membunuh kuman kusta, akan tetapi cacat yang telah terlanjur akan permanen atau menetap, sehingga harus dilakukan upaya perawatan diri. ${ }^{9}$

Kondisi penderita kusta sebelum adanya KPD (Kelompok Perawatan Diri), mereka cenderung bersifat tertutup, tidak memiliki kepercayaan diri, merasa malu dengan penyakit yang dideritanya dan berjuang sendiri untuk mendapatkan pelayanan kesehatan, serta berusaha mencari pengobatan sendiri. ${ }^{10}$ Penderita kusta yang bergabung dengan KPD memiliki kualitas hidup yang lebih baik dibandingkan dengan penderita kusta yang tidak bergabung dengan KPD. ${ }^{11}$

Tolak ukur keberhasilan penyelenggaraan sebuah KPD, yakni sehubungan dengan Prevention of Disabilities (POD). Fasilitator melakukan pemantauan atau memonitor para anggota melalui pemeriksaan yang dilakukan pada setiap pertemuan, memperhatikan perkembangan psikis dan sosial dari penderita. Peran dari KPD dalam upaya pencegahan peningkatan kecacatan di antaranya membantu dalam memecahkan masalah atau persoalan baik fisik, psikis, sosial maupun ekonomi yang diakibatkan karena kusta yang diderita, memberikan anjuran untuk menggunakan bahan yang dapat diperoleh dengan mudah di lingkungan sekitar untuk melakukan perawatan diri, melakukan pemantauan secara efektif dan efisien kepada penderita, serta melakukan rujukan sedini mungkin kepada penderita kusta. $^{12}$

Kabupaten Jember telah membentuk KPD di lima puskesmas, diantaranya Puskesmas Jenggawah, Puskesmas Tempurejo, Puskesmas Sumberbaru, Puskesmas Wuluhan, dan Puskesmas Puger. Terdapat 2 puskesmas saja yang masih melanjutkan kegiatan walaupun dalam pelaksanaannya juga terdapat hambatan, yakni KPD Cahaya di Puskesmas Jenggawah dan KPD Anggrek di Puskesmas Sumberbaru. Selain itu prevalensi kejadian kusta tertinggi pada tahun 2018, yakni pada Puskesmas Jenggawah sebesar
1,56/10.000 penduduk dan Puskesmas Sumberbaru sebesar 2,97/10.000 penduduk, lebih besar jika dibandingkan dengan tiga puskesmas lainnya. Berdasarkan hal tersebut, peneliti ingin menggambarkan peran KPD dalam upaya mencegah peningkatan kecacatan pada penderita kusta di Kabupaten Jember.

\section{METODE}

Penelitian ini merupakan penelitian deskriptif yang dilakukan di KPD Cahaya Puskesmas Jenggawah dan KPD Anggrek Puskesmas Sumberbaru Kabupaten Jember pada bulan Mei 2019. Jumlah sampel penelitian sebanyak 27 responden dan 2 responden di ekslusi, karena meninggal dan menderita penyakit lain, yakni psoriasis dengan menggunakan total population atau sampel jenuh. Responden dalam penelitian ini adalah anggota KPD Cahaya Puskesmas Jenggawah dan KPD Anggrek Puskesmas Sumberbaru baik yang telah selesai pengobatan maupun yang masih dalam proses pengobatan.

Data yang dikumpulkan dalam penelitian ini menggunakan data primer dan data sekunder. Data primer didapatkan dari proses wawancara dan observasi. Data sekunder didapatkan dari prevalensi kasus kusta di Kabupaten Jember dari tahun 2015-2018, jumlah KPD di Kabupaten Jember, jumlah penderita kusta yang telah terdaftar di masing-masing KPD di Kabupaten Jember. Data tersebut diperoleh dari Dinas Kesehatan Kabupaten Jember, Puskesmas Jenggawah, Puskesmas Puger, Puskesmas Sumberbaru, Puskesmas Tempurejo dan Puskesmas Wuluhan.

Teknik pengumpulan data yang dilakukan, yaitu dengan wawancara menggunakan kuesioner dan observasi. Variabel dalam penelitian ini adalah karakteristik responden (usia, jenis kelamin, tingkat pendidikan, jenis pekerjaan, pendapatan rumah tangga, tipe kusta, tingkat kecacatan dan lama bergabung dengan KPD), pendampingan fasilitator dan peran KPD serta ketersediaan sarana dan prasarana dalam melakukan perawatan diri. Teknik analisis data dengan statistik deskriptif. Pengamatan terhadap tabel frekuensi yang terdiri dari kolom-kolom yang memuat frekuensi dan persentase untuk setiap kategori atau variabel yang diteliti. Peneliti menggunakan Pedoman Pelaksanaan Pembentukan Kelompok Perawatan Diri sebagai dasar dalam pembuatan kuesioner. Pada penelitian ini menggunakan Precede Proceed Planning Model Theory dari Green dan Kreuter.

\section{HASIL DAN PEMBAHASAN Karakteristik Responden}

Berdasarkan hasil penelitian yang disajikan dalam tabel 1. menunjukkan bahwa rata-rata usia penderita kusta adalah 44,11 tahun dengan standar deviasi 17,85 tahun. Sebagian besar responden berjenis kelamin laki-laki sebanyak 18 responden $(66,7 \%)$. Tingkat pendidikan dilihat 
berdasarkan jenjang sekolah formal yang pernah atau sedang ditempuh oleh responden. Data menunjukkan bahwa persentase tertinggi yakni tidak sekolah, tamat SD atau tidak tamat SD/sederajat dan tidak tamat SMP/sederajat masuk dalam kategori pendidikan dasar sebanyak 20 responden $(74,1 \%)$. Jenis pekerjaan menunjukkan bahwa responden yang bekerja sedikit lebih banyak dibandingkan yang tidak bekerja sebesar $(33,3 \%)$. Rata-rata pendapatan rumah tangga sebesar Rp 1.574.074,07 dengan nilai tengah sebesar Rp 1.000.000,00, sedangkan pendapatan maksimum dan minimum responden berturut-turut sebesar Rp 9.000.000,00 dan Rp 500.000,00.

Tabel 1. Karakteristik responden

\begin{tabular}{|c|c|c|c|}
\hline Karakteristik Responden & $\bar{x}( \pm \mathrm{SD})$ & $\mathbf{n}$ & $\%$ \\
\hline \multicolumn{4}{|l|}{ Usia } \\
\hline Mean & 44,11 & & \\
\hline Std. Deviasi & 17,85 & & \\
\hline \multicolumn{4}{|l|}{ Jenis Kelamin } \\
\hline Laki-laki & & 18 & 66,7 \\
\hline Perempuan & & 9 & 33,3 \\
\hline \multicolumn{4}{|l|}{ Tingkat Pendidikan } \\
\hline Dasar & & 20 & 74,1 \\
\hline Menengah & & 6 & 22,2 \\
\hline Tinggi & & 1 & 3,7 \\
\hline \multicolumn{4}{|l|}{ Jenis Pekerjaan } \\
\hline Tidak bekerja & & 9 & 33,3 \\
\hline Sekolah & & 0 & 0 \\
\hline PNS/TNI/Polri/BUMN/ & & 0 & 0 \\
\hline \multicolumn{4}{|l|}{ BUMD } \\
\hline Pegawai swasta & & 0 & 0 \\
\hline Wiraswasta & & 0 & 0 \\
\hline Petani/Buruh tani & & 5 & 18,5 \\
\hline Nelayan & & 0 & 0 \\
\hline Buruh/Sopir/ & & 0 & 0 \\
\hline \multicolumn{4}{|l|}{ Pembantu Rumah Tangga } \\
\hline Lainnya & & 13 & 48,1 \\
\hline \multicolumn{4}{|l|}{ Tipe Kusta } \\
\hline Tipe PB & & 2 & 7,4 \\
\hline Tipe MB & & 25 & 92,6 \\
\hline \multicolumn{4}{|l|}{ Tingkat Kecacatan } \\
\hline Tanpa cacat & & 17 & 63 \\
\hline Cacat 1 & & 5 & 18,5 \\
\hline Cacat 2 & & 5 & 18,5 \\
\hline \multicolumn{4}{|l|}{ Lama Bergabung di KPD } \\
\hline Mean & 6,44 & & \\
\hline Std. Deviasi & 3,08 & & \\
\hline Total & & 27 & 100 \\
\hline
\end{tabular}

Tipe kusta yang dialami responden mayoritas tipe MB sebanyak 25 responden $(92,6 \%)$ dengan tingkat kecacatan sebagian besar tanpa cacat yakni sebanyak 17 responden (63\%), cacat 1 dan 2 masing-masing (18,5\%). Lamanya bergabung dengan KPD yakni rata-rata responden bergabung di KPD 6,44 tahun dengan nilai tengah 7 tahun.

\section{Pendampingan Fasilitator KPD}

Tabel 2. Distribusi frekuensi responden menurut peran KPD melalui pendampingan oleh fasilitator

\begin{tabular}{|c|c|c|}
\hline Pertanyaan & Ya $(\%)$ & Tidak (\%) \\
\hline $\begin{array}{l}\text { Responden mengetahui yang } \\
\text { menjadi fasilitator KPD }\end{array}$ & $25(92,6)$ & $2(7,4)$ \\
\hline $\begin{array}{l}\text { Fasilitator menjelaskan tentang } \\
\text { tujuan dari KPD }\end{array}$ & 27 (100) & $0(0)$ \\
\hline $\begin{array}{l}\text { Fasilitator selalu mengingatkan } \\
\text { setiap akan ada pertemuan KPD }\end{array}$ & $3(11,1)$ & $24(88,9)$ \\
\hline $\begin{array}{l}\text { Fasilitator memberikan } \\
\text { penjelasan dan memperagakan } \\
\text { cara melakukan perawatan diri }\end{array}$ & 27 (100) & $0(0)$ \\
\hline $\begin{array}{l}\text { Fasilitator KPD memberi } \\
\text { motivasi untuk teratur melaku- } \\
\text { kan perawatan diri setiap hari }\end{array}$ & $27(100)$ & $0(0)$ \\
\hline $\begin{array}{l}\text { Fasilitator KPD memberi } \\
\text { motivasi untuk aktif dalam } \\
\text { mengikuti kegiatan KPD }\end{array}$ & $24(88,9)$ & $3(11,1)$ \\
\hline $\begin{array}{l}\text { Fasilitator memotivasi untuk } \\
\text { sembuh sejak pertama kali } \\
\text { diketahui menderita kusta }\end{array}$ & $27(100)$ & $0(0)$ \\
\hline $\begin{array}{l}\text { Fasilitator KPD menyampaikan } \\
\text { untuk tidak khawatir tentang } \\
\text { penyakit kusta }\end{array}$ & 27 (100) & $0(0)$ \\
\hline $\begin{array}{l}\text { Fasilitator KPD menyampaikan } \\
\text { bahwa kusta bukan penyakit } \\
\text { turunan }\end{array}$ & $27(100)$ & $0(0)$ \\
\hline $\begin{array}{l}\text { Fasilitator KPD menyampaikan } \\
\text { bahwa kusta bukan penyakit } \\
\text { kutukan }\end{array}$ & $27(100)$ & $0(0)$ \\
\hline $\begin{array}{l}\text { Fasilitator KPD } \\
\text { menginformasikan tentang } \\
\text { dampak jika tidak rutin } \\
\text { melakukan perawatan diri }\end{array}$ & 27 (100) & $0(0)$ \\
\hline $\begin{array}{l}\text { Fasilitator KPD menyampaikan } \\
\text { bahwa penyakit kusta dapat } \\
\text { sembuh dengan berobat dan } \\
\text { melakukan perawatan diri } \\
\text { secara teratur }\end{array}$ & 27 (100) & $0(0)$ \\
\hline
\end{tabular}

Tabel 3. Pendampingan oleh fasilitator KPD

\begin{tabular}{lcc}
\hline Pendampingan oleh Fasilitator KPD & n & \% \\
\hline Baik & 27 & 100 \\
Tidak baik & 0 & 0 \\
\hline Total & 27 & 100 \\
\hline
\end{tabular}




\section{Peran KPD}

Tabel 4. Distribusi frekuensi peran KPD menurut responden

\begin{tabular}{|c|c|c|}
\hline Pertanyaan & Ya $(\%)$ & $\begin{array}{l}\text { Tidak } \\
(\%)\end{array}$ \\
\hline \multicolumn{3}{|l|}{ Membantu memecahkan masalah } \\
\hline Membantu merawatan diri (menutup/membersihkan luka, mengolesi kulit kering dengan minyak & $18(66,7)$ & $9(33,3)$ \\
\hline $\begin{array}{l}\text { Mengingatkan tentang risiko pekerjaan yang dilakukan seperti mencangkul, memotong, menggergaji } \\
\text { dan lain-lain yang dapat menimbulkan luka }\end{array}$ & $27(100)$ & $0(0)$ \\
\hline Menyarankan untuk istirahat sampai sembuh jika muncul luka & $23(85,2)$ & $4(14,8)$ \\
\hline Menyarankan untuk menggunakan alas kaki, sarung tangan, kacamata saat di rumah & $27(100)$ & $0(0)$ \\
\hline Memberikan solusi jika malu datang ke KPD & $8(29,6)$ & $19(70,4)$ \\
\hline Memotivasi penerimaan kondisi atau cacat tubuh yang dialami & $26(96,3)$ & $1(3,7)$ \\
\hline Menyemangati ketika awal diberitahu mengidap kusta & $25(92,6)$ & $2(7,4)$ \\
\hline Menunjukkan manfaat bergabung dengan KPD & $27(100)$ & $0(0)$ \\
\hline Memberi waktu untuk menceritakan masalah yang dihadapi & $27(100)$ & $0(0)$ \\
\hline Memberikan solusi terhadap masalah yang tengah dihadapi & $27(100)$ & $0(0)$ \\
\hline Memberikan bantuan saat terjadi masalah & $27(100)$ & $0(0)$ \\
\hline Mengadakan kegiatan yang dapat meningkatkan dan memberdayakan anggota dari segi ekonomi & $17(63)$ & $10(37)$ \\
\hline Memberikan bantuan untuk membantu perekonomian & $11(40,7)$ & $16(59,3)$ \\
\hline Memberikan bantuan berupa alat pelindung diri (APD) & $18(66,7)$ & $9(33,3)$ \\
\hline \multicolumn{3}{|l|}{ Memberikan anjuran } \\
\hline Menyarankan untuk melakukan perawatan diri di luar kegiatan KPD & $24(88,9)$ & $3(11,1)$ \\
\hline Menyarankan perawatan secara mandiri di rumah & $24(88,9)$ & $3(11,1)$ \\
\hline Menyaankan jenis bahan-bahan yang digunakan untuk melakukan perawatan diri & $25(92,6)$ & $2(7,4)$ \\
\hline Memberikan penjelasan bahan untuk melakukan perawatan diri & $26(96,3)$ & $1(3,7)$ \\
\hline Menjelaskan bahan untuk melakukan perawatan diri dapat diperoleh di lingkungan sekitar & $26(96,3)$ & $1(3,7)$ \\
\hline Menjelaskan bahan untuk melakukan perawatan diri dapat dijangkau atau murah & $26(96,3)$ & $1(3,7)$ \\
\hline \multicolumn{3}{|l|}{ Melakukan pemantauan } \\
\hline Memantau perkembangan kesehatan setiap KPD & $27(100)$ & $0(0)$ \\
\hline Mencatat perkembangan kesehatan setiap KPD & $27(100)$ & $0(0)$ \\
\hline Memiliki buku pemeriksaan untuk memantau perkembangan kesehatan & $27(100)$ & $0(0)$ \\
\hline Menanyakan ketidakhasiran dalam KPD & $15(55,6)$ & $12(44,4)$ \\
\hline Menanyakan perkembangan kesehatan kepada rekan yang lain jika tidak hadir KPD & $27(100)$ & $0(0)$ \\
\hline Meminta bantuan keluarga untuk memantau perkembangan kesehatannya & $15(55,6)$ & $12(44,4)$ \\
\hline \multicolumn{3}{|l|}{ Merujuk } \\
\hline Memberi penjelasan tentang reaksi kusta & $17(63)$ & $10(37)$ \\
\hline $\begin{array}{l}\text { Memberi penjelasan jika tidak melakukan perawatan diri secara rutin akan menimbulkan kecacatan } \\
\text { yang semakin parah }\end{array}$ & $27(100)$ & $0(0)$ \\
\hline $\begin{array}{l}\text { Memberi penjelasan jika timbul reaksi yang semakin parah dan tidak dapat dirawat lagi dengan } \\
\text { perawatan diri dan perawatan di puskesmas akan langsung dirujuk }\end{array}$ & $17(63)$ & $10(37)$ \\
\hline Memberi penjelasan tentang rumah sakit rujukan kusta & $17(63)$ & $10(37)$ \\
\hline
\end{tabular}

Tabel 5. Kategori Peran KPD menurut responden

\begin{tabular}{lcccc}
\hline \multirow{2}{*}{ Peran KPD } & Baik & \multicolumn{3}{c}{ Tidak baik } \\
\cline { 2 - 5 } & $\mathbf{n}$ & $\mathbf{\%}$ & $\mathbf{n}$ & $\mathbf{\%}$ \\
\hline Memecahkan masalah & 27 & 100 & 0 & 0 \\
Memberikan anjuran & 25 & 92,6 & 2 & 7,4 \\
Melakukan pemantauan & 24 & 88,9 & 3 & 11,1 \\
Merujuk & 17 & 63 & 10 & 37 \\
\hline
\end{tabular}


Sarana dan Prasarana

Tabel 6. Sarana dan prasarana dalam melakukan perawatan diri di KPD

\begin{tabular}{lc}
\hline \multicolumn{1}{c}{ Sarana dan prasarana } & Ketersediaan \\
\hline Tempat pertemuan & Tersedia \\
Barang-barang demonstrasi & Tidak \\
Daftar kehadiran atau presensi & Tidak \\
Buku pemeriksaan KPD & Tersedia \\
Sumber air bersih & Tersedia \\
Baskom & Tersedia \\
Batu apung & Tersedia \\
Sabun & Tersedia \\
Garam & Tersedia \\
Minyak atau lotion & Tersedia \\
Brosur, leaflet, dan sebagainya & Tersedia \\
Alat Pelindung Diri (APD) & Tidak \\
\hline
\end{tabular}

Karakteristik responden merupakan ciri-ciri yang melekat pada responden yang dapat memberikan gambaran mengenai identitas dari responden. Karakteristik responden dalam penelitian ini merupakan faktor predisposisi yang dapat mempengaruhi seseorang dalam berperilaku. Faktor predisposisi merupakan faktor penguat dari dalam individu yang berupa karakteristik seseorang atau populasi yang memotivasi perilaku sebelum atau selama terjadinya perilaku. $^{13}$

Karakteristik responden yang dimaksud yakni, ratarata usia penderita kusta dalam penelitian ini adalah 44 tahun. Usia tersebut masuk dalam kategori usia produktif. Hasil penelitian ini sesuai dengan yang dilakukan oleh Chrisnina bahwa rata-rata usia penderita kusta adalah 34,95 tahun yang berada dalam kelompok dewasa tengah. Dunia dewasa banyak orang yang melakukan aktivitas di luar rumah, sehingga meningkatkan risiko terpaparnya kuman kusta. $^{14}$

Responden yang berjenis kelamin laki-laki lebih banyak dibandingkan dengan perempuan dengan perbandingan 2:1. Berdasarkan hasil penelitian yang dilakukan oleh Nabila et al di Rumah Sakit Kusta Kediri, didapatkan penderita yang mengalami kusta berdasarkan jenis kelamin lebih banyak terjadi pada laki-laki sebesar $75 \%$, sedangkan perempuan sebesar $25 \%$ dan adanya kecenderungan tidak memakai pakaian di kehidupan seharihari pada laki-laki, diyakini meningkatkan kemungkinan risiko tertular kusta melalui kontak kulit. ${ }^{15}$ Laki-laki lebih banyak menderita kusta karena laki-laki kurang memperhatikan kebersihan diri dibandingkan dengan perempuan, sehingga meningkatkan risiko tertular kusta. Selain itu jenis kelamin juga akan mempengaruhi kecacatan yang dialami oleh penderita kusta. Penderita kusta laki-laki lebih sering mengalami kecacatan, salah satunya karena aktivitas berat yang dilakukan sehari-hari. ${ }^{16}$
Sebagian responden berpendidikan dasar, yakni tidak tamat Sekolah Dasar dan Sekolah Menengah Pertama bahkan tidak sekolah atau tidak pernah mengenyam bangku sekolah. Pendidikan rendah dapat mengakibatkan kurangnya pengetahuan penderita kusta terhadap penyakit kusta, dan nantinya akan berpengaruh terhadap rendahnya kepatuhan dalam pengobatan. ${ }^{16}$ Pengetahuan merupakan suatu domain penting dalam pembentukan perilaku seseorang. Orang dengan pengetahuan yang baik cenderung akan lebih bertanggung jawab dengan kondisi kesehatannya dibandingkan dengan yang memiliki pengetahuan kurang, sehingga cenderung akan mengabaikan upaya pencegahan terhadap suatu penyakit yang dialami termasuk dalam hal perawatan diri yang dilakukan oleh penderita. Semakin tinggi tingkat pendidikan, makin tinggi pula pengetahuannya, maka akan bertambah baik perawatan diri yang dilakukan. ${ }^{17}$

Responden yang bekerja sedikit lebih banyak dibandingkan yang tidak bekerja. Berdasarkan hasil penelitian responden bekerja sebagai penjual ikan keliling, penjual bakpao, penjual sayur di pasar, penjaga sekolah, bekerja di bengkel, tenaga honorer di sekolah, pelukis, mencari keong disawah untuk dijual. Selain itu beberapa responden juga bekerja sebagai petani atau buruh tani, hal ini sesuai dengan data dari Badan Pusat Statistika Kabupaten Jember (2018) sebagian besar rumah tangga di Kecamatan Jenggawah dan Kecamatan Sumberbaru berturut-turut yakni $90,3 \%$ dan $66,3 \%$ memiliki pekerjaan sebagai petani/ buruh tani ${ }^{(18)}$ Pekerjaan yang berat dan kasar serta intensitas pekerjaan yang tidak teratur seperti petani dan buruh, sehingga memudahkan timbulnya kecacatan. ${ }^{16}$

Rata-rata pendapatan rumah tangga responden sebesar Rp 1.574.074,07 sedangkan pendapatan maksimum dan minimum responden berturut-turut sebesar Rp 9.000.000,00 dan Rp 500.000,00. Pendapatan merupakan salah satu tolok ukur kesanggupan seseorang atau keluarga dalam memperoleh pelayanan kesehatan. ${ }^{19}$ Orang dengan pendapatan yang cukup untuk memenuhi kebutuhan primer dan bisa memenuhi kebutuhan sekunder akan menyediakan waktu untuk melakukan pengobatan atau perawatan untuk dirinya, tetapi orang dengan pendapatan rendah akan merasa berat jika harus mengurangi waktu kerja atau meninggalkan pekerjaannya karena akan mengurangi penghasilan mereka untuk memenuhi kebutuhan hidup sehari-hari. ${ }^{20}$

Mayoritas responden menderita kusta tipe MB sebesar 92.6\%. Kusta tipe PB dan MB dibedakan berdasarkan lesi kulit dan kerusakan saraf. Kusta tipe MB jumlah bercak yang mati rasa lebih dari 5 dan terdapat penebalan saraf tepi pada lebih dari satu saraf sedangkan untuk tipe PB jumlah bercak yang mati rasa yaitu 1-5 dan penebalan saraf tepi hanya pada satu saraf. ${ }^{21}$ Orang yang kontak serumah dengan penderita tipe MB mempunyai risiko lebih tinggi yakni 4-10 kali dibandingkan dengan orang yang 
kontak serumah dengan penderita tipe PB, yakni 2 kali. $^{22}$ Penularan terjadi apabila kuman kusta utuh (solid) yang berasal dari pasien kusta tipe MB yang belum diobati atau tidak teratur berobat. Penderita kusta tipe MB mempunyai peluang 10 kali kecacatan jika dibandingkan dengan penderita tipe $\mathrm{PB} .{ }^{17}$

Tingkat kecacatan yang dialami responden sebagian besar tanpa cacat sebanyak 17 responden (63\%) sedangkan sisanya cacat 1 dan cacat 2 sebesar (18,5\%). Seseorang yang mengalami tanpa cacat tidak ada kelainan yang terjadi. Sementara untuk seseorang yang mengalami cacat 1 terdapat kelainan pada mata, tetapi tidak terlihat, visus sedikit atau jarak pandang berkurang dan terdapat anastesi serta kelemahan pada otot. Cacat 2 merupakan tingkat kecacatan yang paling parah yakni terdapat kelainan pada mata seperti lagoftalmos, kekeruhan kornea dan visus sangat terganggu, terdapat kerusakan pada tangan atau kaki seperti ulkus, jari kriting dan kaki semper. ${ }^{7}$

Berdasarkan hasil penelitian pada pelaksanaan KPD anggota yang tidak mengalami kecacatan akan membantu anggota yang lain dalam hal perawatan seperti membantu menggosok kulit yang menebal dengan batu apung, mengolesinya dengan minyak atau lotion pada kulit yang kering. Sedangkan pada anggota yang mengalami kecacatan tertentu memang membutuhkan perawatan khusus untuk mata, tangan maupun kaki. Perawatan dan latihan tersebut tidak sama untuk semua penderita bergantung pada jenis kecacatan yang dialami, seperti: perawatan untuk tangan yang bengkok akan dilatih dengan cara meluruskan sendisendinya untuk mencegah agar tidak sampai terjadi kekakuan yang lebih berat, untuk kaki yang semper dapat dilakukan latihan dengan cara menggunakan kain panjang atau sarung yang dikaitkan pada bagian depan kaki yang semper dan ditarik ke arah tubuh penderita.

Rata-rata responden bergabung dengan KPD, yakni 6,44 tahun. Lama seseorang mengikuti KPD berpengaruh terhadap paparan informasi tentang perawatan diri, sehingga nantinya akan berpengaruh pula pada aktivitas perawatan diri yang dilakukan. Perawatan diri yang baik dapat membantu memperbaiki tingkat kecacatan lebih dari 50\% yang dialami penderita kusta 4 tahun terdeteksi. ${ }^{16}$

\section{Pendampingan Fasilitator KPD}

Pendampingan yang dilakukan fasilitator dapat dikatakan sudah baik. Penilaian tersebut didasarkan pada beberapa tugas yang dilakukan oleh fasilitator dalam KPD. Fasilitator menjelaskan kepada calon-calon anggota mengapa mereka diundang mengikuti KPD, sehingga calon anggota mengetahui tujuan dari KPD itu sendiri. Selain itu, terkait pertemuan untuk kegiatan KPD fasilitator dan para anggota mendiskusikan tanggal dan waktu pertemuan yang sesuai untuk semua pihak yang terlibat didalamnya. Pada saat awal pertemuan KPD mereka akan diberi undangan, kemudian untuk kelanjutannya akan didiskusikan waktu yang tepat untuk pertemuan. Pertemuan untuk KPD Cahaya Puskesmas Jenggawah dilaksanakan pada hari Sabtu Legi setiap 35 hari sekali, sedangkan pertemuan untuk KPD Anggrek Puskesmas Sumberbaru dilaksanakan pada hari rabu tiap bulannya. Penentuan waktu yang konsisten akan memudahkan anggota karena mudah diingat, sehingga fasilitator tidak mengingatkan kembali setiap akan ada pertemuan KPD.

Tugas fasilitator selanjutnya adalah memberikan penjelasan dan memperagakan tentang cara melakukan perawatan diri. Pada awal-awal pertemuan, dasar-dasar untuk perawatan diri akan dijelaskan kepada para anggota, biasanya perawatan untuk luka akan lebih diutamakan, karena memang luka perlu dirawat sesegera mungkin. Memberikan motivasi untuk aktif dalam mengikuti kegiatan di KPD, memberi semangat kepada anggota serta menciptakan suasana dimana semua anggota dapat melibatkan diri dalam kegiatan kelompok.

Petugas kesehatan atau perawat dalam pelayanan kesehatan berfungsi sebagai comforter atau pemberi rasa nyaman, protector dan advocate (pelindung dan pembela), communicator, mediator dan rehabilitator. Selain itu juga peran dari petugas kesehatan adalah sebagai tempat konseling dapat dijadikan sebagai tempat bertanya oleh individu, keluarga, kelompok maupun masyarakat untuk memecahkan masalah yang dihadapi. ${ }^{23}$

\section{Peran KPD}

\section{Peran KPD dalam membantu memecahkan masalah}

Seseorang yang menderita kusta akan mengalami permasalahan yang sangat kompleks tidak hanya dari segi fisik berupa kecacatan jika tidak segera diobati da ditangani, melainkan pada masalah psikis, sosial maupun ekonomi. ${ }^{24}$ Penderita akan kehilangan pekerjaan, merasa malu, minder bahkan putus asa, ada keinginan untuk mengasingkan diri dari keluarga dan lingkungan sekitar karena ditakutkan penyakitnya akan menularkan kepada orang lain. Berdasarkan tabel 5 masih terdapat responden, yakni 29,6\% yang malu untuk datang ke KPD. Padahal dengan adanya KPD dapat menjadi solusi dalam mengatasi permasalahan kecacatan dan masalah sosial ekonomi yang dialami oleh penderita kusta, selain itu juga KPD merupakan strategi nasional dalam upaya pengendalian penyakit kusta melalui pemberdayaan terhadap anggota.

Anggota yang tergabung di KPD merasakan manfaat mengikuti kegiatan di KPD. Anggota berkumpul untuk saling memberikan dukungan satu dengan lainnya, saling membantu dalam mengatasi permasalahan akibat kusta yang diderita. Pada saat pertemuan KPD anggota diberikan waktu untuk menceritakan masalah yang dihadapi. Beberapa responden menyampaikan masalah yang diceritakan berkaitan dengan penyembuhan luka atau perawatan diri 
serta masalah keuangan. Setelah menceritakan masalah yang dihadapi ada solusi yang diberikan dan merasa lebih terbantu, seperti diberi pinjaman uang walau hanya Rp $50.000,00$ oleh anggota yang bersedia memberikan bantuan pinjaman.

Peran KPD dalam upaya membantu penyembuhan luka selain berupa perawatan diri di KPD dapat pula berupa pemberian bantuan alat pelindung diri berupa sandal ataupun sepatu. Bantuan tersebut didapatkan oleh beberapa anggota yang memang membutuhkannya terutama untuk anggota yang mati rasa pada kaki. APD merupakan salah satu prinsip dari perawatan diri pada klien kusta. Pemakaian APD untuk mendukung kesembuhan dan meminimalisir tingkat kecacatan yang lebih parah dengan cara pemakaian alat pelindung diri pada mata, tangan maupun kaki. ${ }^{25}$

Beberapa kegiatan di KPD Cahaya Puskesmas Jenggawah yang dapat membantu anggota dalam memecahkan masalah ekonomi, diantaranya: bantuan kambing bergulir, pelatihan keterampilan membuat kerajinan dan aksesoris, program beasiswa, dan pemberian simpan pinjam, serta bedah kamar.

\section{Peran KPD dalam memberikan anjuran menggunakan bahan yang dapat diperoleh untuk perawatan diri.}

Mayoritas responden, yakni 92,6\% mengetahui bahan-bahan yang digunakan untuk melakukan perawatan diri terutama perawatan diri pokok yakni: batu apung, ember, air, minyak kelapa. Bahan-bahan untuk perawatan diri dapat diperoleh dengan mudah dan murah dilingkungan sekitar tanpa membutuhkan biaya yang besar, hal tersebut disampaikan oleh responden. Ada responden yang juga membuat sendiri bahan untuk perawatan diri dengan minyak kelapa dari kelapa tua yang kemudian diparut diambil sari patinya di masak hingga menghasilkan minyak. Minyak kelapa yang dihasilkan nanti akan digunakan untuk mengolesi tangan atau kaki agar tetap lembab.

Selain itu juga perawatan luka dengan menggunakan madu dapat digunakan pada saat pertemuan KPD. Perawatan diri dengan menggunakan madu luka yang dialami oleh penderita kusta menjadi bersih dan jaringan sekitar luka tidak terjadi penebalan. Madu mampu melakukan debridemen luka melalui aktivasi autolisis protease. Autolisis protease ini diaktivasi oleh hidrogen peroksida yang dilepaskan oleh madu. ${ }^{26}$

\section{Peran KPD dalam melakukan pemantauan secara efektif dan efisien}

Pemantauan yang dilakukan KPD efektif dan efisien dengan memantau perkembangan anggota setiap pertemuan dan dilakukan pencatatan pada buku pemeriksaan yang dilakukan oleh fasilitator KPD, selain itu juga meminta bantuan kepada keluarga untuk memantau perkembangan kesehatan anggota, dengan harapan ada perkembangan kesehatan yang jauh lebih baik dari sebelumnya. Pada setiap pertemuan KPD, anggota selalu dipantau perkembangan kesehatannya dan di catat dalam buku pemeriksaan yang dimiliki oleh setiap anggota. Ketika anggota tidak hadir dalam kegiatan KPD petugas menanyakan alasan ketidakhadirannya, akan tetapi dari KPD juga memahami ketika anggota tidak datang mengikuti kegiatan. Ketidakhadiran anggota pada kegiatan KPD dikarenakan sebagian besar dari anggota adalah tulang punggung keluarga yang harus bekerja untuk memenuhi kebutuhan hidup keluarga.

Petugas dari KPD meminta bantuan keluarga untuk memantau perkembangan kesehatan dan membantu dalam melakukan perawatan, akan tetapi ada beberapa responden yang tidak tinggal bersama keluarganya. Dukungan keluarga sangatlah penting. Dukungan keluarga yang adekuat dalam perawatan diri akan membantu penderita dalam mentaati peraturan yang ada sehubungan dengan perawatan diri penderita kusta, baik frekuensi perawatan hingga tata cara yang tepat dalam melakukan perawatan diri. ${ }^{17}$ Hal ini dikarenakan keluarga merupakan orang terdekat dari penderita yang dapat diminta nasehat maupun pendapat. Anggota keluarga berfungsi untuk mendampingi penderita dalam pelatihan perawatan diri, memberikan dukungan secara emosional terhadap perawatan diri penderita kusta seperti pemberian semangat, motivasi, mengingatkan untuk tetap rutin dalam melakukan perawatan diri. ${ }^{27}$

\section{Peran KPD dalam melakukan rujukan}

Sebagian besar pasien yang mengalami reaksi dapat ditangani oleh petugas di puskesmas, namun ada kalanya harus dirujuk ke rumah sakit baik rumah sakit umum maupun rumah sakit khusus untuk menangani kusta. Pasien dapat dirujuk tergantung pada tipe reaksi yang dialami oleh penderita dan berat ringannya reaksi yang terjadi, ada tidaknya komplikasi atau kontra indikasi yang dapat mempengaruhi penanganan reaksi, dan ketersediaan obat untuk penderita, serta tingkat kemampuan penanganan yang tersedia di puskesmas. ${ }^{7}$ Berdasarkan tabel 11 masih terdapat responden sebanyak $37 \%$ yang belum mendapatkan penjelasan terkait reaksi kusta, sehingga dari petugas kesehatan diharapkan dapat menyampaikan penjelasan tentang reaksi kusta kepada anggota dengan penyampaian yang mudah difahami dan cara yang inovatif.

Penderita kusta yang perlu dirujuk ke rumah sakit selain pasien darurat yang mengalami reaksi, penderita cacat yang membutuhkan pembedahan rekonstruksi serta penderita kusta yang memang membutuhkan alas kaki khusus. Alas kaki akan dibuat sesuai dengan bentuk kaki yang cacat, sehingga anggota KPD perlu dirujuk ke rumah sakit yang bersangkutan. Rumah Sakit rujukan untuk penderita kusta, yakni Rumah Sakit Sumberglagah Mojokerto merupakan rumah sakit khusus untuk menangani kusta yang terletak di 
Kecamatan Pacet, Kabupaten Mojokerto, Selain itu, juga ada penderita kusta yang dirujuk ke Rumah Sakit dr. Soebandi Jember karena memang berdasarkan Pedoman Pelaksanaan Pembentukan Kelompok Perawatan Diri RS Umum daerah seharusnya dapat menerima semua kasus yang dapat ditangani oleh rumah sakit tersebut.

\section{Sarana dan Prasarana}

Berdasarkan hasil observasi sarana dan prasarana dalam melakukan perawatan diri dapat dikatakan kurang lengkap karena ada beberapa perlengkapan yang tidak tersedia yakni barang-barang demonstrasi, daftar kehadiran atau presensi, dan Alat Pelindung Diri (APD). Barang demonstrasi yang dimaksud dalam hal ini misalnya panci dengan pegangan kayu, kain untuk membungkus pegangan benda panas atau kasar, kain untuk menutup luka, tongkat untuk berjalan, pipa rokok dari bambu. ${ }^{12}$ Barang demonstrasi tersebut digunakan untuk memudahkan anggota dalam melakukan aktivitasnya seperti memasak, bekerja dan sebagainya agar terhindar dari luka.

Kehadiran para anggota dicek diawal pertemuan KPD dan dicatat pada formulir kehadiran atau presensi. Keaktifan anggota hadir di KPD dapat dilihat dari presensi atau daftar kehadiran yang tersedia. Penelitian terdahulu menyatakan bahwa, penderita kusta yang aktif mengikuti kegiatan KPD memiliki nilai rata-rata kecacatan sebesar 0,83 lebih rendah jika dibandingkan dengan yang tidak aktif mengikuti kegiatan KPD yakni sebesar 2,57. ${ }^{16}$

Alat Pelindung Diri untuk penderita kusta terdiri dari alat pelindung untuk melindungi mata seperti kaca mata hitam, kaki dengan alas kaki sandal atau sepatu khusus, serta alat pelindung tangan berupa sarung tangan. APD bertujuan untuk menghindari atau mencegah bahkan mengurangi kecacatan yang terjadi pada penderita kusta. Manfaat pemakaian APD agar kecacatan pada penderita kusta tidak bertambah berat, karena mengingat memang kecacatan yang sudah terlanjur pada penderita kusta akan tetap ada seumur hidup, sehingga penderita kusta harus melakukan perawatan diri dengan menggunakan APD. ${ }^{25}$

Tempat pertemuan untuk pelaksanaan KPD sudah tersedia, karena tempat pertemuan berpengauh besar terhadap keberhasilan suata KPD dan tidak harus ditempatkan di puskesmas, rumah salah satu anggota atau kepala desa dapat dijadikan tempat pertemuan. Tempat diluar puskesmas diharapkan dapat meningkatkan keberanian anggota untuk datang dan masyarakat secara tidak langsung mendapat kesempatan untuk belajar mengenai kusta dan mengatasi rasa takut terhadap kusta. ${ }^{12}$ Perlengkapan perawatan diri pokok (baskom, batu apung, sabun, garam, minyak atau lotion) serta bahan informasi sepert leaflet, brosur, flipchart (lembar balik) tersedia di KPD. Penggunaan media dalam penyampaian informasi akan memudahkan anggota menerima informasi

\section{SIMPULAN}

Rata-rata usia penderita kusta yang tergabung dengan KPD adalah 44,11 tahun, termasuk dalam kategori usia produktif dan sebagian besar berjenis kelamin laki-laki dengan tingkat pendidikan dasar yaitu tidak sekolah, tamat atau tidak tamat $\mathrm{SD} /$ sederajat dan tidak tamat SMP/ sederajat. Jenis pekerjaan menunjukkan bahwa yang bekerja lebih banyak dibandingkan dengan yang tidak bekerja, yakni sebagai petani/ buruh tani dan pekerjaan lainnya. Rata-rata pendapatan keluarga sebesar Rp 1.574.074,07. Tipe kusta yang dialami mayoritas tipe MB (Multibacilarry) dengan tingkat kecacatan sebagian besar tanpa cacat sebesar 63\% sedangkan cacat 1 dan 2 masing-masing sebesar 18,5\%. Lama bergabung dengan KPD, rata-rata 6,44 tahun.

Seluruh responden menilai baik terkait pendampingan yang dilakukan oleh fasilitator KPD yang didasarkan pada tugas fasilitator diantaranya, menjelaskan tujuan KPD pada awal pertemuan, mendiskusikan waktu yang sesuai untuk kegiatan, memberikan penjelasan dan memperagakan dalam hal perawatan diri, memberikan motivasi dan semangat untuk anggota KPD.

Penilaian peran didasarkan pada tugas-tugas dari KPD. Hasil observasi sarana dan prasarana dalam melakukan perawatan diri dinilai kurang lengkap, karena terdapat beberapa perlengkapan yang tidak tersedia, yakni barang-barang demonstrasi, daftar kehadiran atau presensi, dan Alat Pelindung Diri (APD).

\section{Ucapan Terima Kasih}

Ucapan terima kasih dan penghargaan yang setinggitingginya diberikan kepada seluruh responden yang telah bersedia untuk menjadi bagian dari penelitian ini, serta seluruh pihak yang telah membantu dari awal hingga akhir.

\section{KEPUSTAKAAN}

1. WHO. Global leprosy update, 2017: reducing the disease burden due to leprosy. Weekly Epidemiologycal Record. 2018.

2. Kemenkes RI. infoDatin-kusta-2018_2.pdf. Jakarta; 2018. p. 4.

3. Aditia N, Besuki EK, Putra NA, Hanim A. Penentuan Pusat Pertumbuhan Ekonomi Dalam Pengembangan Wilayah. 2017;IV(1):109-16.

4. Dinas Kesehatan Jember. Data Prevalensi Penderita Kusta di Kabupaten Jember Tahun 2015-2018. Jember; 2018.

5. Deniati, K., Saepulloh, Mekar R. Hubungan Stigma Masyarakat dengan Tingkat Partisipasi Keluarga dalam Perawatan Klien Kusta di Desa Karangsari Kecamatan Negalsari Tangerang Banten Tahun 2012. 2012;

6. Putri MA, Harmayetty, Utomo B. Psycoeducative Family Therapy Mempengaruhi Pengetahuan , Dukungan Keluarga Dan Stigma Kusta. J Ners. 2016;11(Rafferty):88-98. 
7. Kemenkes RI. Pedoman Nasional Program Pengendalian Penyakit Kusta. 2016.

8. Mulyadi A, Sepdianto TC, Mitayasari E. Upaya Penderita Kusta Dalam Mencegah Peningkatan Derajat Kecacatan. J Ners dan Kebidanan. 2017;4(3):186-91.

9. Hartanti RD, Listyorini L, Karima M. Perawatan Diri Pasien Kusta. J Ilm Kesehat. 2015;7(1).

10. Indriani YA, Santoso B. Upaya PerMaTa (Perhimpunan Mandiri Kusta) dalam Membangun Kapital Sosial pada Komunitas Orang Kusta di Kecamatan Jenggawah Kabupaten Jember ( Efforts of PerMaTa ( Independent Leprosy Association ) in Building Social Capital among Leprous People in Distr. 2014;1(I):83-9.

11. Ulfa, F. Kualitas Hidup Orang Yang Pernah Menderita Kusta (OYPMK). 2015;

12. Depkes RI. Pedoman Pelaksanaan Pembentukan Kelompok Perawatan Diri. 2006.

13. Ririanty, M. Fakultas Kesehatan Masyarakat Universitas Jember Jl Kalimantan MI. Komunikasi Kesehatan Program Family Folder Dalam Penanggulangan TB Ditinjau Dari Teori PrecedeProceed Health Communication Family Folder Program in Response TB Viewed of Precede-Proceed Theory. J IKESMA. 2014;10(2):10.

14. Chrisnina. Hub Dukungan Keluarga Dengan Interaksi Sosial.Pdf. 2015;

15. Nabila, S. D. Profil Penderita Penyakit Kusta Di Rumah Sakit Kusta Kediri Periode Januari 2010 Sampai Desember 2010. Saintika Med. 2017;8(2):707.

16. Latifa A. Perbedaan Tingkat Kecacatan Penderita Kusta yang Aktif dan Tidak Aktif Mengikuti Kegiatan Kelompok Perawatan Diri (KPD) di Kabupaten Jember. 2015;27.

17. Nur, L. A. F. Hubungan Dukungan Keluarga Dan Pengetahuan Terhadap Perawatan Diri Penderita Kusta Di Puskesmas Grati Tahun 2016. Indones J
Public Heal. 2017;12(1):13.

18. Badan Pusat Statistika Kabupaten Jember. Profil Kecamatan Jenggawah dan Sumberbaru dalam Angka Tahun 2018. (c):2-6.

19. Notoatmodjo, S. Promosi Kesehatan dan Perilaku Kesehatan. Jakarta: Rineka Cipta; 2012.

20. Mahanani, N. Faktor-faktor yang Berhubungan dengan Perawatan Diri Kusta pada Penderita Kusta di Puskesmas Kunduran Kecamatan Kunduran Kabupaten Blora Tahun 2011. Univ Negeri Semarang. 2013;53-66.

21. Andini, F., Efrida, W., Arif, E. A. Morbus Hansen Tipe Multibasiler (Mid Borderline) dengan Reaksi Kusta Reversal dan Kecacatan Tingkat I. J Medula. 2017;7(2):30-6.

22. Gustam TYP, Agusni I, Nuswantoro D. Hubungan antara Riwayat Kontak dengan Kejadian Kusta Multibasiler. 6th Univ Res Colloq 2017. 2018;35-9.

23. Khotimah, M. Hubungan Antara Dukungan Keluarga dan Peran Petugas Kesehatan dengan Kepatuhan Minum Obat Kusta di Kabupaten Blora Tahun 2011. Unnes J Public Heal. 2014;3(2):1-5.

24. Roziqoh. Hubungan Perawatan Diri dan Pemberian Motivasi dari Kelompok Perawatan Diri dengan Tingkat Kepercayaan Diri Penderita kusta Kabupaten Situbondo. 2013;

25. Huzzein, E.C., Rahmawati, I., Susanto, T. Hubungan Pemakaian Alat Pelindung Diri dengan Tingkat Kecacatan Klien Kusta di Wilayah Kerja Puskesmas Jenggawah dan Tempurejo Kabupaten Jember Tahun 2014 (The Correlation of Application Universal Precaution for Prevent Degree of Disability Clients Lepros. e-Jurnal Pustaka Kesehat. 2014;3(1):89-95.

26. Subiakto. Perbedaan Efektifitas Antara Perawatan Luka Terhadap Perbaikan Luka Kusta Di Rumah Sakit. Depok: Universitas Indonesia; 2008.

27. Susilowati, D. dan Widya H. Dukungan Keluarga dalam Kegiatan Kelompok Perawatan Diri (KPD) Penderita Kusta di Kabupaten Brebes. 2016;(2). 